\title{
Ethnobotanical Uses, Phytochemistry and Pharmacological Activities of Pterocarpus marsupium: A Review
}

\author{
Mohd Saidur Rahman, Md. Mujahid*, Mohd Aftab Siddiqui, Md. Azizur Rahman, Muhammad Arif, \\ Shimaila Eram, Anayatullah Khan, Md Azeemuddin
}

\section{Mohd SaidurRahman, Md. Mujahid", Mohd Aftab Siddiqui, Md. Azizur Rahman, Muhammad Arif, Shimaila Eram, Anayatullah Khan, Md Azeemuddin}

\section{Department of Pharmacy, Herbal} Bioactive Research Laboratory, Faculty of Pharmacy, Integral University, Lucknow, Uttar Pradesh -226026, INDIA.

\section{Correspondence}

Dr. Md. Mujahid

Faculty of Pharmacy, Integral University, Lucknow, Uttar Pradesh, INDIA.

Phone no : +917236955641

E-mail: mujahidiu@gmail.com

\section{History}

- Submission Date: 31-03-2018;

- Review completed: 02-05-2018;

- Accepted Date: 03-10-2018

\section{DOI : 10.5530/pj.2018.6s.1}

Article Available online

http://www.phcogj.com/v10/i6s

\section{Copyright}

(C) 2018 Phcog.Net. This is an openaccess article distributed under the terms of the Creative Commons Attribution 4.0 International license.

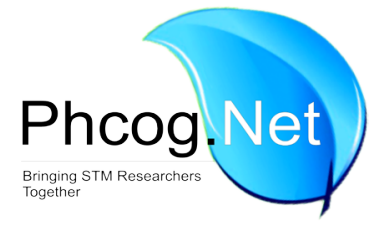

\begin{abstract}
Pterocarpus marsupium is an important therapeutic and medicinal plant belonging to family Fabaceae and commonly named as Indian Kino tree, Bijasal, Venga or Vijayasara. It is a huge deciduous plant and widely distributed in the Central, Western and Southern regions of India. Role of P. marsupium is found in Ayurveda, Homeopathic and Unani systems of medicine. It is a decent source of tannins and flavonoids hence, used as influential astringent, anodyne, cooling, regenerating agent and also used for the treatments of leprosy, leucoderma, toothache, fractures, diarrhea, passive hemorrhage, and dysentery, bruises and diabetes. It is also used to treat rheumatoid arthritis, gout, diabetic anemia, indigestion, asthma, cough, discoloration of hair, bronchitis, ophthalmic complications, elephantiasis and erysipelas. Researchers have been stated the presence of several phytoconstituents in P. marsupium and also their pharmacological activities. The current review aimed to define the phytochemical and pharmacological aspects of $P$. marsupium which will have been help in the researchers for further qualitative research.
\end{abstract}

Key words: Pterocarpus marsupium, Indian Kino, Phytochemistry, Pharmacology, Antidiabetic, Antioxidant, Tannin, Epicatechin.

\section{INTRODUCTION}

Plants are important to human being for his life. Plants are continuously a common source of remedy in the usage of traditional preparations. All plants phyla produce authorized and unauthorized product of therapeutic importance. The antiquity of herbal remedy is as ancient as human society. The treasure of India is stored in the vast natural flora, which has been boon to mankind. India is virtually herbarium of the planet. ${ }^{1-2}$ Although the biologically active phytoconstituents of certain herbal drugs are unknown, they are prescribed commonly owing to their efficacy, least side effects in clinical information and comparatively very low costs. ${ }^{3}$ Pterocarpus marsupium plant belonging to family Fabaceae has been used in India and its adjacent countries due to its various biological activities from ancient times. All parts of $P$. marsupium is used as a primitive medicine for domestic remedy against several human diseases. It has been broadly used in Homoeopathic, Ayurvedic and Unani systems of medicine. ${ }^{4-5}$ It is a deciduous tree, generally known as Malabar or Indian Kino tree (Table 1) ${ }^{6-7}$ It is present especially in Western Ghats areas, Karnataka-Kerala regions and found in Madhya Pradesh, Bihar, Gujarat and Orissa. ${ }^{8}$ Traditionally, the plant product are being used as cooling, external application as anthelminthic, headache, antipyretic, anti-inflammatory, aphrodisiac, in mental aberrations, biliousness and ulcers. ${ }^{9}$ Phytochemical studies have revealed that the plant contains terpenoids, aurone and isoflavonoids glycosides and associated phenolic compounds, lupenol, epicatechin, $\beta$-sitosterol..$^{10} P$. marsupium is the very rich sources of flavonoid and polyphenolic compounds. ${ }^{11}$ Its heartwood possesses anti-inflammatory, astringent, anodyne and antidiabetic properties and also cataract, hypertriglyceridemia, cardiotonic, hepatoprotective activity and as a selective inhibitor of COX-2. ${ }^{12-15}$

\section{Characteristics}

P. marsupium is a large, deciduous plant which can grow up to 30 meters in height. ${ }^{18}$ Its stem bark is of grey brown color. Heart wood is yellowish golden in color and bark products are reddish gum. ${ }^{19-20}$ Leaves are large green colored, compound, imparipinnate and having 3-7 inches length, 5-8 leaflets, margin curly and thick. From leaflet to leaflet, the petioles are round, flat, undulated and long up to 5 or 6 inches and not having stipules. ${ }^{19-20}$ Different parts of P. marsupium are shown in Figure 1. Flowers are $1.5 \mathrm{~cm}$ long, white with a minor yellow tinge with 10 stamens. Anthers are 2 lobed..$^{19}$ Pods are brown, glabrous, flat, orbicular, winged like, $3-6 \mathrm{~cm}$ in width, usually single seeded and curved convexly. There are almost $1500-2000$ pods $/ \mathrm{kg}^{21}$ Seeds are kidney shaped 1 to 1.3 centimeter long, reddish
Cite this article: Rahman MS, Mujahid Md, Siddiqui MA, Rahman MS, Arif M, Eram S, Khan A Azeemuddin Md. Ethnobotanical uses, Phytochemistry and Pharmacological Activities of Pterocarpus marsupium: A Review. Pharmacog J. 2018;10(6)Suppl:s1-s8. 
Table 1: Scientific classification and vernacular names of Pterocarpus marsupium.

\begin{tabular}{|c|c|}
\hline Scientific classification ${ }^{1}$ & Vernacular names. ${ }^{16,1,17}$ \\
\hline Synonym: IndianKino, Bijasal, & Urdu: Bijasar \\
\hline Vijayasagar, Bibla, Malbar kino. & Sanskrit: Bijaka, Pitasara, Asana, \\
\hline Family: Fabaceae. & Bijasara \\
\hline Domain: Eukaryota. & Assamese: Aajar \\
\hline Kingdom: Plantae. & Bengali: Piyasala, Pitasala \\
\hline Subkingdom: Viridaeplantae. & English: Indian Kino \\
\hline Phylum: Magnoliophyta. & Gujrati: Biyo \\
\hline Subphylum: Euphyllophytina. & Hindi: Vijayasara, Bija \\
\hline Class: Magnoliopsida. & Kannada: Bijasara, Asana \\
\hline Subclass: Rosidae. & Kashmiri: Lal Chandeur \\
\hline Super order: Fabanae. & Malayalam: Venga \\
\hline Order: Fabales. & Marathi: Bibala \\
\hline Genus: Pterocarpus. & Oriya: Piashala \\
\hline \multirow[t]{3}{*}{ Species: Marsupium. } & Punjabi: Lal Chandan, Channanlal \\
\hline & Tamil: Vengai \\
\hline & Telugu: Yegi, Vegisa \\
\hline
\end{tabular}

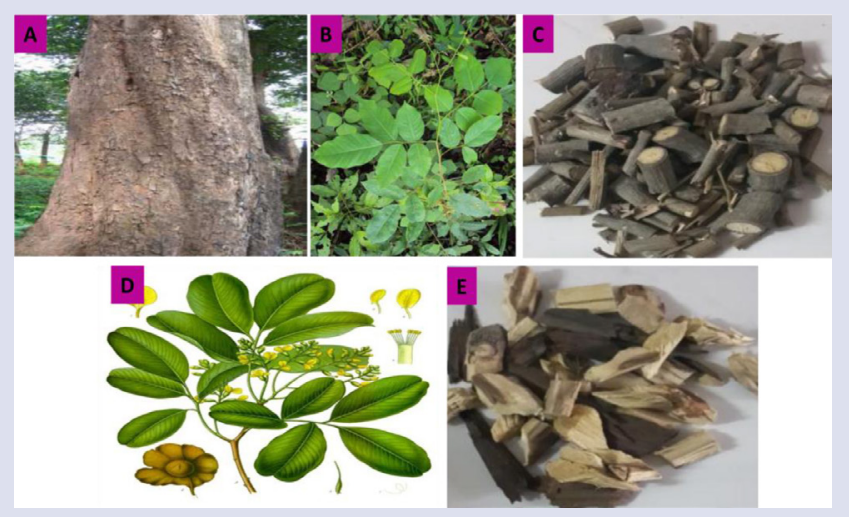

Figure 1: Different parts of the plant P. marsupium. (A). Bark, (B). Leaves, (C). Heartwood, (D). Twig, (E). Small branches. ${ }^{19-22}$

brown, fairly rigid with smooth glossy leathery testa. ${ }^{21}$ Legume is swallowed on a lengthy, petiole is three, fourths or bicular, the upper remains, which spreads from pedicel to the rest of style is straight, the entire covered with a downy, waved, veiny, layered wing, enlarged, woody center and where seed is blocked and not opening. ${ }^{20}$

\section{Origin, distribution and habitat}

P. marsupium is growing in defoliate and evergreen jungles of Southern, Western and Central regions of India. It is present generally in Gujarat, Bihar, West Bengal, Orissa, Uttar Pradesh, Western Ghats, Kerala, Karnataka, and Madhya Pradesh, of prominent India, Srilanka and Nepal. It develops generally on hills or undulating lands or rocky grounds up to a height of 150 to 1100 meter. The usual rainfall of its habitat ranges starting from 750 to $2000 \mathrm{~mm}$ and even more in Southern India. The maximum temperature was ranged from $35^{\circ} \mathrm{C}$ to $48^{\circ} \mathrm{C}$ and minimum temperature was ranged from $0^{\circ} \mathrm{C}$ to $18^{\circ} \mathrm{C}$. It can increase in huge variety of soils and geographical situations like quartzite, shale, conglomerates, lateritic, gneiss and sandstone. It favors well-drained sandy and sedimentary soil to loamy soil. The species is adequate light loving and the young seedlings are frost-tender. ${ }^{18,21,23}$
Table 2: Traditional uses of various parts of Pterocarpus marsupium.

\begin{tabular}{|c|c|c|}
\hline Plant part(s) & Uses & References \\
\hline Leaves & $\begin{array}{l}\text { Fractures, constipation, hemorrhages } \\
\text { skin diseases, depurative, ophthalmology, } \\
\text { leprosy, rectalgia, and leucoderma, } \\
\text { rheumatoid arthritis, skin diseases, } \\
\text { external use for sores, boils, stomach } \\
\text { pain and gastrointestinal disorders. }\end{array}$ & {$[1,25,26,2,19,16]$} \\
\hline Bark & $\begin{array}{l}\text { Diuretic, cholera, dysentery, } \\
\text { stomachache, tongue diseases, urinary } \\
\text { complaints and toothache, astringent, } \\
\text { treatment of tumors of the gland, } \\
\text { urethral discharges, chronic ulcers, } \\
\text { abortifacient. }\end{array}$ & {$[27,16]$} \\
\hline Stem & Neurological problems. & {$[1,25]$} \\
\hline \multirow[t]{2}{*}{ Heartwood } & Control blood sugar level. & {$[1,25,26]$} \\
\hline & $\begin{array}{l}\text { Astringent, bitter acrid, anti- } \\
\text { inflammatory, anthelmintic, anodyne }\end{array}$ & {$[12]$} \\
\hline Flower & Fever. & {$[16]$} \\
\hline Gum-Kino & $\begin{array}{c}\text { Diarrhea, passive hemorrhages, } \\
\text { leucorrhoea, dysentery. }\end{array}$ & \\
\hline
\end{tabular}

\section{TRADITIONAL USES}

P. marsupium has been traditionally used in the treatment of leucoderma, elephantiasis, diarrhea, cough, discoloration of hair and rectalgia. ${ }^{14}$ It is nontoxic and useful in jaundice, fever, wounds, diabetes, stomachache and ulcer (Table 2 and 3 ). ${ }^{24}$

\section{PHYTOCONSTITUENTS}

Earlier researchers recognized the plant $P$. marsupium as a very rich source of flavonoids and polyphenolic compounds. All the active phytoconstituents of $P$. marsupium were thermostable. It contains pterostilbene (45\%), alkaloids $(0.4 \%)$, tannins (5\%) and protein. ${ }^{19}$ The primary phytoconstituents were liquiritigenin, isoliquiritigenin, pterostilbene, pterosupin, epicatechin, catechin, kinotannic acid, kinoin, kino red, $\beta$-eudesmol, carsupin, marsupial, marsupinol, pentosan, $p$-hydroxybenzaldehyde (Table 4, Figure 2). ${ }^{16,28}$

\section{MARKETED PRODUCT}

DRF/AY/5001 composed of $P$. marsupium, Terminalia chebula, Emblica officinalis and Momordica charantia extracts; Diabecon composed of Pterocarpus marsupium, Glycyrrhiza glabra, Asparagus and Gymnema sylvestre extracts; Diabeta composed of Pterocarpus marsupium, Zingiber officinale, Acacia Arabica, Tinospora cordifolia, Curcuma langa, Gymnema sylvestre and Azadiractha indica extracts; and Silbinol containing $P$. marsupium bark and heartwood extracts are the different marketed formulations of $P$. marsupium. ${ }^{39-44}$

\section{REPORTED PHARMACOLOGICAL ACTIVITIES OF PTEROCARPUS MARSUPIUM}

\section{Antidiabetic activity}

The ethanolic extract of $P$. marsupium stem wood has antidiabetic activity. The highest blood glucose lowering effect (57.56\%) was found in $180 \mathrm{~min}$ for standard drug glimepiride along with for ethanolic extract at a dose of $200 \mathrm{mg} / \mathrm{kg}$ b. wt. (51.30\%) and at $400 \mathrm{mg} / \mathrm{kg}$ b. wt. (55.13\%). The extract showed antidiabetic activity which is dose and time dependent. ${ }^{45}$ The ethanolic extract of heartwood ( $1 \mathrm{gm} / \mathrm{kg}$ per oral and $2 \mathrm{gm} / \mathrm{kg}$ per oral) significantly $(p<0.05)$ reduced the raised glucose levels in Wistar 


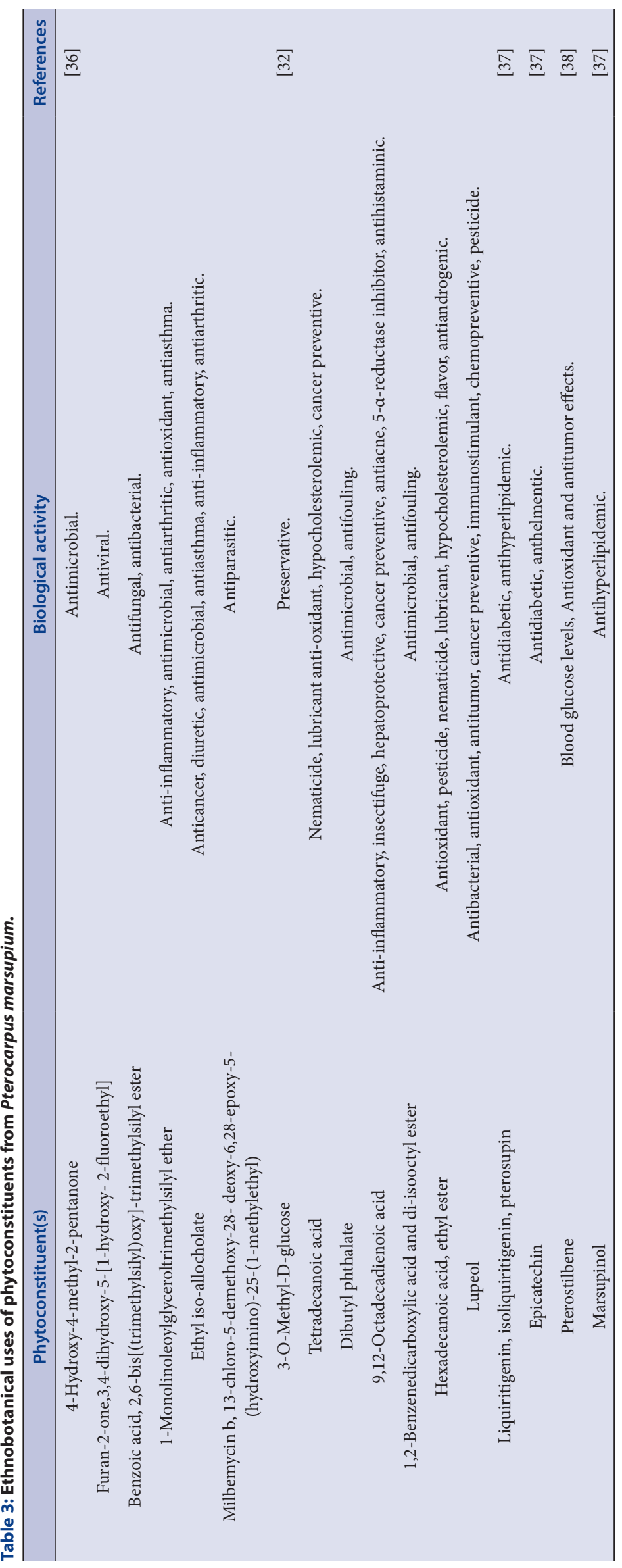

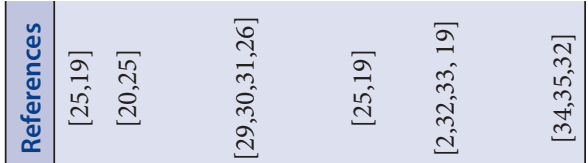

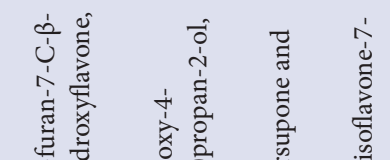

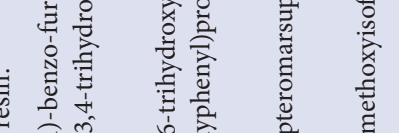

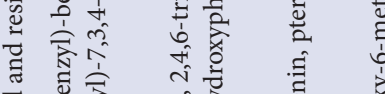

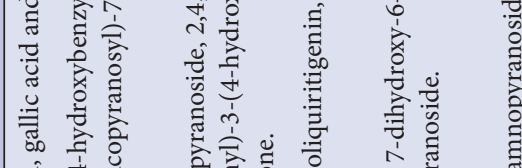

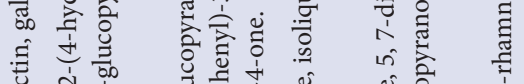

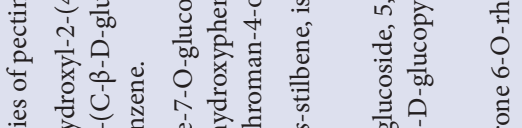

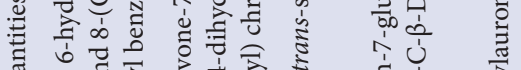
䒕 记

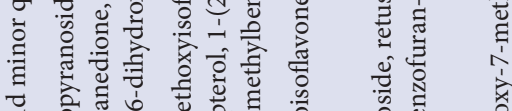

ฯ

馬 பิ

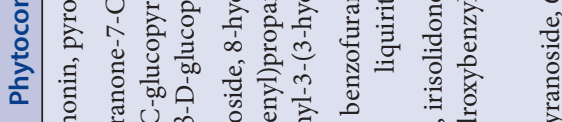

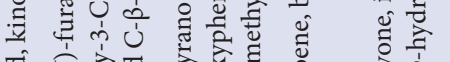

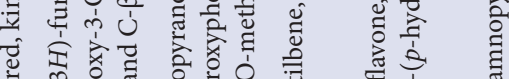

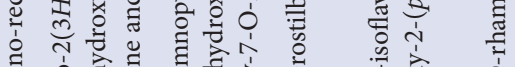

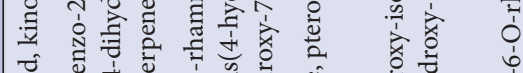

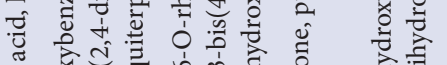

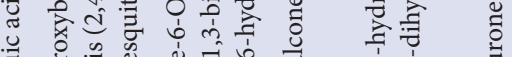

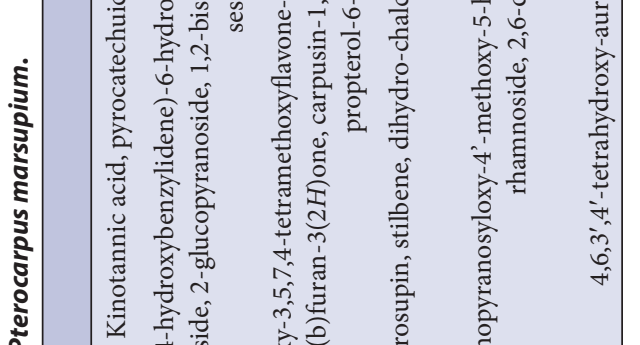




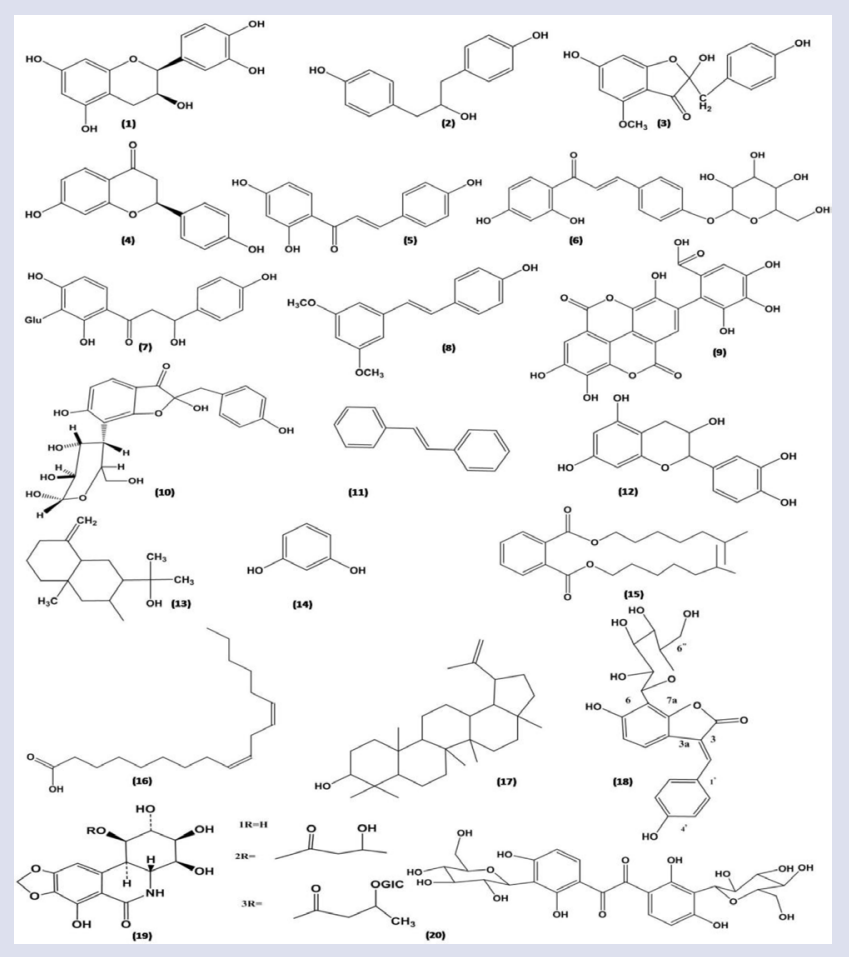

Figure 2: Chemical structures of important phytoconstituents from P. marsupium: Epicatechin (1), propterol (2), marsupin (3), liquiritigenin (4), isoliquiritigenin (5), isoliquiritin (6), pterosupin (7), pterostlbene (8), kinotannic acid (9), 2,6-dihydroxy-2-( $p$ hydroxybenzyl)-3(2H)-benzofuran-7-C- $\beta$-D-glucopyranoside (10), trans-stilbene (11), (-)-catechin (12), $\beta$-eudesmol (3), resorcinol (14), 1,2-benzenedicarboxylic acidiisooctyl ester (15), 9,12-octadecadienoic acid (16), lupeol (17), pterocarposide (18), 6-hydroxy-3,5,7,4'tetramethoxyflavone-6-rhamnoside (19), vijayosin (20).

male albino rats showing antidiabetic effect in dexamethasone-induced hyperglycemia and hyperinsulinemia. ${ }^{46}$

Marsupsin and Pterostilbene the most important phenolic compounds of the heartwood after intraperitoneal administration using each dose $40 \mathrm{mg} / \mathrm{kg}$ b.wt. Considerably decreased the level of blood glucose in hyperglycemic rat with hyperglycemia caused by streptozotocin mostly useful in non-insulin dependent diabetes mellitus (NIDDM) with obesity matched with control metformin. All these compounds Marsupsin, Pterosupin and liquiritigenin decreased the body weight of albino rats..$^{37,47}$

P. marsupium methanol extract activates the glucose transport in a PPAR $\gamma$ mediated PI3 kinase dependent fashion on Glut-4, PPAR $\gamma$ and PI3 kinase while the P. marsupium isoflavone exerted the same glucose transport activity in an alternate mechanism, PPAR $\gamma$ mediated but PI3 kinase independent fashion. ${ }^{48}$

Aqueous extract $(200 \mathrm{mg} / \mathrm{kg})$ considerably $(p<0.001)$ reduced the raised level of chronic systemic inflammation cytokine TNF- $\alpha$ at both doses in type-2 diabetic rats. ${ }^{49,50}$

Aqueous extract showed significant effect in NIDDM induced by administering streptozocin $90 \mathrm{mg} / \mathrm{kg}$ i.p on cytokine TNF- $\alpha$ because of its isoflavone components. It was originated to be raised cytokine TNF- $\alpha$ in non-treated diabetic rats because of prolonged systemic inflammation. Aqueous extract at both doses (100 and $200 \mathrm{mg} / \mathrm{kg}$ b.wt.) significantly reduced the raised TNF- $\alpha$ level in rats. ${ }^{51}$
Aqueous extract of heart wood P. marsupium stimulated the insulin secretion and glucose uptake in mouse muscle and pancreatic tissues with concentration dependent manner which included higher concentration $(10$ and $100 \mu \mathrm{L})$ and lower concentration $(0.1$ and $1 \mu \mathrm{L})$. Bioassay showed fractionation of extract had potent antidiabetic properties in vitro and in vivo. The extract acted via different pathways which are utilized by insulin because insulin presence did not show any effect on extractmediated muscle glucose. ${ }^{52}$

\section{CNS activity}

(-)-Epicatechin was separated from the bark and it was established for its action on CNS of rats, mice and frog. It was examined that (-)-epicatechin don't have any effect on CNS of rats, mice and frog. (-)-Epicatechin had been showing positive chronotropic and inotropic effects on the heart of frog and propranolol use to block this effect. Hyperglycemia is produced in rats at higher doses (200 and $500 \mathrm{mg} / \mathrm{kg} \mathrm{b}$. wt.) of this compound and this effect is also prevented by propranolol indicating adrenergic activity. ${ }^{53}$

\section{Antihyperlipidemic activity}

Effect of combination therapy with methanolic extract of Ocimum sanctum leaves and P. marsupium heart wood was studied on non-diabetic and oxidative stressed alloxan induced diabetic Wistar rats (female). Dosage of $500 \mathrm{mg} / \mathrm{kg}$ b.wt. of both mixture of methanolic extract of Ocimum sanctum leaves and P. marsupium heart wood analyzed has shown significant effect on dyslipidemia and also maintain endogenous antioxidant levels in non-diabetic and oxidative stressed alloxan induced diabetic female Wistar rats model. ${ }^{54-55}$

Ethanolic wood and bark extracts of P. marsupium $(150+150 \mathrm{mg} / \mathrm{kg}$ b.wt.) significantly decreased blood glucose and lipid in albino Wistar rats where diabetes was induced by giving alloxan monohydrate $(150 \mathrm{mg} / \mathrm{kg}$, i.p) for 14 days. $^{32,37}$

\section{Antioxidant activity}

Ethanol, isopropyl alcohol (IPA) and acetone stem wood extracts of P. marsupium showed antioxidant activity in 2,2-diphenyl-1-picrylhydrazyl (DPPH) radical scavenging method. ${ }^{45}$ Methanolic extract $(100 \mu \mathrm{g} / \mathrm{ml})$ is achieved to have maximum 2,2-diphenyl-1-picrylhydrazyl free radical scavenging effect followed by ethyl acetate and aqueous extracts. The scavenging effect achieved saturation with further increase in concentration of extracts. This study had showed significant antioxidant activity of $P$. marsupium bark extract in DPPH, superoxide, ABTS, hydroxyl radical, nitric oxide scavenging and suppression of in vitro lipid peroxidation. ${ }^{56}$

The in vitro antioxidant activity of ethyl acetate leaf extract of P. marsupium was studied by using DPPH assay, hydroxyl radical scavenging activity, ABTS assay, FRAP assay, NO radical scavenging activity, TRAP assay, reducing power assay and hydrogen peroxide $\left(\mathrm{H}_{2} \mathrm{O}_{2}\right)$ radical scavenging activity. The leaf extract has showed higher scavenging activity i.e. $71 \%$ in FRAP assay at a concentration of $100 \mu \mathrm{g} / \mathrm{ml}$. This study showed that the ethyl acetate leaf extract of $P$. marsupium have free radical scavenging activity. ${ }^{57}$

Extract prolonged the cardiac arrest time by $14 \mathrm{~min}$ when compared with the control in oxidative stress model where it was induced by $1 \mathrm{mM}$ of $\mathrm{H}_{2} \mathrm{O}_{2}$ and cardiac arrest was the end point. It was found that $P$. marsupium extract had significant antioxidant activity in isolated frog heart. ${ }^{58}$

The alcoholic extract of $P$. marsupium of varying concentrations showed inhibitory effect as evident by $\mathrm{IC}_{50}$ of $55.39 \mu \mathrm{g} / \mathrm{ml}, 195.88 \mu \mathrm{g} / \mathrm{ml}$, $151.00 \mu \mathrm{g} / \mathrm{ml}$ on advanced glycation end products formation, rat kidney aldose reductase and sorbitol accumulation respectively. This research 
suggests that the photo extract exhibited promising role in decreasing/ delaying diabetic complications. ${ }^{59}$

\section{Hepatoprotective activity}

Histology and liver biomarkers (serum protein, total bilirubin, alanine amino transaminase, alkaline phosphatase and aspartate amino transaminase) results shown that methanol and aqueous stem bark extracts ( $25 \mathrm{~m} / \mathrm{kg}$ per day per oral for 14 days) possesses significant hepatoprotective effect in carbon tetrachloride $\left(\mathrm{CCl}_{4}\right)$ induced hepatotoxicity model. ${ }^{14}$

Levels of the enzymes (lactate dehydrogenase, aspartate transaminase, alkaline phosphatase, alanine transaminase and bilirubin) were considerably reduced in the group treated with plant extracts $(100 \mathrm{mg} / \mathrm{kg}$ b.wt orally) in $\mathrm{CCl}_{4}$ induced hepatotoxicity model. The investigation suggested that plant was having good protecting effect on $\mathrm{CCl}_{4}$ induced hepatotoxicity. ${ }^{60}$

\section{Antidiarrheal activity}

Ethanolic extract of P. marsupium heartwood (250 and $500 \mathrm{mg} / \mathrm{kg}$ b.wt.) significantly decreased the severity and frequency of charcoal and castor oil induced gastrointestina motility or diarrhea confirming the strength of traditional use of this plant as the modality for diarrhea. ${ }^{61}$

\section{Anticancer activity}

Anticancer activity of pterostilbene, a constituent of plant of $P$. marsupium was evaluated in A-375, HCT-116, Hep-G2, MDAMB- 231 and PC-3 cell lines by measuring cell viability after treatment with pterostilbene $(1,10$, 50 and $100 \mu \mathrm{g} / \mathrm{ml}$ ). The $\mathrm{IC}_{50}$ of each cell line were $16.0 \mu \mathrm{M}$ (Hep-G2), $40.6 \mu \mathrm{M}$ (MDA-MB-231), $45.3 \mu \mathrm{M}$ (HCT-116), $421 \mu \mathrm{M}$ (A-375), $3.9 \mathrm{mM}$ (PC-3). This study showed that pterostilbene high activity against Hep-G2 (liver) and HCT-116 (colon) cancers and it was not active in PC-3. ${ }^{62}$ Effects of pterostilbene, an active constituent of P. marsupium, on cell viability in human gastric carcinoma AGS cells were investigated. It was found that pterostilbene was able to inhibit cell proliferation and induce apoptosis in a concentration and time dependent manner. Pterostilbene induced apoptosis in AGS cells through activating the caspase cascade via the mitochondrial and Fas/FasL pathway, GADD expression and by modifying cell cycle progress and changes in several cycle-regulating proteins. Antitumor effect of pterostilbene was proved by induction of apoptosis. $^{63}$

\section{Antimicrobial activity}

Antimicrobial activity of aqueous and methanolic bark extracts of P. marsupium was evaluated by using disc diffusion method. It showed the zone of inhibition ranges from 11-22 mm for different extracts. Methanol extract showed significant effect by preventing $A$. niger at $25 \mu \mathrm{g} / \mathrm{ml}$ and E. faecalis, S. typhi at $12.5 \mu \mathrm{g} / \mathrm{ml}$. It was found that P. marsupium showed significant antimicrobial action against microbes. ${ }^{64}$ Antimicrobial activity of ethanolic extract of $P$. marsupium against Candida albicans, Vibrio cholera and Bacillus polymyxa was evaluated by using cyclic voltammetry. The low anodic current and low anodic peak potential was obtained showing the good decreasing ability of the molecules resulting in good antioxidant potential of the extract. The result showed the significant antimicrobial effect at different dosages. ${ }^{65}$

\section{Antibacterial activity}

Methanolic extract of $P$. marsupium stem was tested by using paper disc diffusion method against gram +ve bacteria Bacillus coagulans and gram +ve bacteria Escherichia coli. $100 \mathrm{mg} / \mathrm{ml}$ concentration significantly inhibited growth of both the bacteria. ${ }^{66}$

The acetone and isopropyl alcohol extract of $P$. marsupium $(50 \mathrm{mg} / \mathrm{ml})$ showed the antibacterial activity against the Gram +ve bacteria (Staphy- lococcus aureus and Bacillus cereu) but did not show antibacterial activity against Gram +ve bacteria (Escherichia coli and Salmonella Typhi). Ethanol extract of $P$. marsupium $(50 \mathrm{mg} / \mathrm{ml})$ did not show any antibacterial activity. ${ }^{45}$

\section{Anti-inflammatory activity}

Methanolic and aqueous extract evaluated anti-inflammatory effect by acute inflammation model using carrageenan induced rat paw edema method. Methanol extract at dose $50 \mathrm{mg} / \mathrm{kg} \mathrm{b}$. wt. and aqueous extract at dose $100 \mathrm{mg} / \mathrm{kg}$ b.wt. indicated significant decrease in paw edema. It was found that both extracts had significant anti-inflammatory activity. ${ }^{67-68}$

P. marsupium aqueous extract at doses of $100 \mathrm{mg} / \mathrm{kg}$ and $200 \mathrm{mg} / \mathrm{kg}$ b.wt was found to decrease the elevated inflammatory cytokine, TNF-a level in NIDDM diabetic rats. ${ }^{69}$

\section{Toxicity study}

Acute toxicity test was performed in mice. For this aqueous extracts of P. marsupium bark was administrated orally at single dose of $2.5-12.5 \mathrm{~g} / \mathrm{kg}$ and examined upto 7 days for general behavior and mortality. The no-observed adverse effect level (NOAEL) and lowest-observed adverse effect level (LOAEL) were $5.0 \mathrm{~g} / \mathrm{kg}, 7.5 \mathrm{mg} / \mathrm{kg}$ b.wt respectively. Mortality was increased with the dose (LD50>10.75 g/kg b. wt) for the mouse. The sub-chronic toxicity test was performed in rats. For this extract was administered daily $150-600 \mathrm{mg} / \mathrm{kg}$ b.wt for 42 days which did not show death or significant changes in biochemical parameters. At the dose of $600 \mathrm{mg} / \mathrm{kg}$ b.wt only increased hepatic catalase activity. No alteration was found in food and water intake and body weight. The histopathology of kidney, lungs, liver and pancreas did not show any morphological alteration. ${ }^{70-71}$

\section{Nootropic activity}

Methanolic extract of P. marsupium ( 25 and $50 \mathrm{mg} / \mathrm{kg}$ p.o.) were administered in adult albino Swiss mice for neurotoxicity test for learning and memory. P. marsupium improved scopolamine induced amnesia with evidence increasing inflexion ratio and reduces transfer latency and improves the impairment of spatial memory induced by scopolamine as indicated by formation of reference and working memories. ${ }^{72}$

\section{Antiulcer activity}

Methanolic heartwood extract of P. marsupium (750 mg/kg b.wt) lowers the blood glucose level in both normal rats and NIDDM rats. It saved the mucosa by influencing the increase in mucosal offensive (LPO and NO) factors and decrease in defensive factors (superoxide dismutase and catalase). It did not indicate any safety against ulceration caused by aspirin, pylorus ligation, cold restraint stress, and ethanol in normal rats. ${ }^{73-74}$

\section{Cardiotonic activity}

Aqueous heartwood extract of P. marsupium shows cardiotonic activity using isolated frog heart perfusion. At a very low concentration $(0.25 \mathrm{mg} / \mathrm{ml})$, a considerable rise in force of contraction and reduced heart rate as compared to standard digoxin. At higher dose $(4 \mathrm{mg} / \mathrm{ml})$ cardiac arrest occurred. The result showed that $P$. marsupium significantly increases contraction force of heart. ${ }^{13}$

\section{COX-2 Inhibition}

P. marsupium extract evaluated for selective cyclo-oxygenase (COX-2) inhibitory action due to presence of pterostilbene. In a whole blood assay method, it is revealed that the dose of $P$. marsupium (450 mg/kg b.wt) did not reduce PGE2 production. During the study, no changes were observed from the base line of the safety parameters and no extract associated adverse effects occurred. ${ }^{15}$ 


\section{Analgesic activity}

The ethyl acetate, petroleum ether and methanol leaf extracts of P. marsupium were evaluated for analgesic activity in Swiss albino mice. Improvement in writhing response of different extract was compared. The methanolic extract at the doses of $120 \mathrm{mg} / \mathrm{kg}$ b.wt was more effective than ethyl acetate and petroleum ether extracts. ${ }^{75}$

Central analgesic effects of $P$. marsupium bark extract was evaluated in mice by using hot plate method. $P$. marsupium bark extract at dose of $500 \mathrm{mg} / \mathrm{ml}$ significantly improved reaction time as compared to standard. ${ }^{76}$

\section{Anticataract activity}

Aqueous bark extract of $P$. marsupium ( $1 \mathrm{~g} / \mathrm{kg} /$ day), alcoholic seeds extract of Trigonella foenum graecum $(2 \mathrm{~g} / \mathrm{kg} / \mathrm{day})$ and leaf extract of Ocimum sanctum (200 mg/kg/day) were analyzed in growth of cataract in diabetic rats. $P$. marsupim treated group showed less opacity index in comparison with controls group and did not exhibited mature stage of cataract. $^{77-78}$

\section{Genotoxic assessment}

It was studied that stem bark extract of $P$. marsupium administered to mice for longer period of time did not show any genotoxic activity. ${ }^{79}$

\section{Aphrodisiac activity}

It was stated the utility of $P$. marsupium as Vajikaran Rasayana of Ayurveda or Aphrodisiac of New concept. ${ }^{80}$

\section{Antifungal activity}

A study was carried for 10 days in which after 7 and 10 days of therapy $78 \%$ and $93 \%$ excellent to good response was found from the alcoholic extract compared to $73 \%$ from the aqueous extract. Thus, it shows that the ointment prepared from alcoholic extract is more effective than aqueous extract. There was no side effect after continuous uses of drug for 10 days. ${ }^{81}$

\section{Anthelmintic activity}

The anthelmintic effect of ethyl acetate, ethanol, $n$-butanol and petroleum ether leaves extract of $P$. marsupium was analyzed by using Indian earthworms as trial worm. Different concentrations of different extracts were tested to determine paralysis and death time of the worm. Albendazole $(10 \mathrm{mg} / \mathrm{ml})$ was used as standard drug. The outcome of this study shown that between all the extract, petroleum ether and ethanol exhibited significant anthelminitic activity as related to reference drug albendazole. ${ }^{82}$

\section{CONCLUSION}

Pharmacologically reported various activities of $P$. marsupium includes antidiabetic, antihyperlipidemic, antioxidant, hepatoprotective, antidiarrhoeal, anticancer, analgesic, antibacterial, anti-inflammatory, cardiotonic, antiulcer and several other activities. Very few examinations have been carried out involving the anticataract, nootropic activity, antifungal, aphrodisiac and anthelmintic activities. Through various phytochemicals were isolated, it helps to achieve its therapeutic value and plays a significant role in modern system of remedy and it requires supplementary exploitation. It is vital to recognize the active components and their molecular interaction, which will help to examine therapeutic value of the product and also homogenize the product. The most significant bioactive components were saponins, terpenoids, tannins, flavonoids, alkaloids and phenolic compounds. The current review elaborated the pharmacological studies, phytochemical studies and ethnobotanical uses of $P$. marsupium and isolated chief phytoconstituents from them, which can be evaluated to discover the lead molecules in the examination of new herbal drugs.

\section{ACKNOWLEDGEMENT}

The authors express their sincere thanks to Department of Pharmacy, Integral University, Lucknow for their encourage and providing research atmosphere (manuscript communication number: IU/R\&D/2018MCN000256).

\section{CONFLICT OF INTEREST}

The authors declare that they have no competing interests.

\section{ABBREVIATIONS}

P. marsupium: Pterocarpus marsupium; CNS: Central Nervous System; b.wt.: Body weight; WHO: World Health Organization; DPPH: 2,2-diphenyl-1-picrylhydrazyl; NMR: Nuclear Magnetic Resonance; TLC: Thin layer chromatography; COX: Cycoloxygenase; ROS: Reactive Oxygen Species; ALT: Alanine transaminase; AST: Aspartate transaminase; MIC: Minimum inhibitory concentration; TNF- $\alpha$ : Tumor necrosis factor- $\alpha$; TRAP assay: Telomeric repeat amplification protocol; FRAP assay: Ferric reducing ability of plasma; NIDDM: Non-insulin dependent diabetes mellitus.

\section{REFERENCES}

1. Devgun M, Nanda A, Ansari SH. Pterocarpus marsupium Roxb. A comprehensive review. Pharmacognosy reviews. 2009;3(6):359.

2. Prathap BC, Rajitha B, Anusha $\mathrm{CH}$, Nagasirisha M, Madhusudhana Chetty $C$, Mohamed Saleem TS. Pterocarpus marsupium Roxb: A potent herb for life threatening diseases. Int J Res Phyt Pharm. 2012(2):75-83.

3. Kathryn AR, Connie MR, Jaime AY, Neal MD. Pharmacometrics of Stilbenes Current Clinical Pharmacology. 2006;1(1):81-101.

4. Gamble JS. Flora of the Presidency of Madras. Adlard and Sons Ltd, London, UK. 1935.

5. Matthew KM. The Flora of Tamil Nadu Carnatic. St. Josephs College, Tiruchirapalli, India. 1983.

6. Abhishek N, Karunakar H. Pharmacological Profile of Pterocarpus marsupium with a note on its Therapeutic Activity: A Review International Journal of Pharma and Chemical Research. 2017;3(1):32-37.

7. Rout SD, Thatoi HN. Ethnomedicinal practices of Kol tribes in Similipal biosphere reserve, Orissa, India. Ethnobotanical Leaflets. 2009;(3):1.

8. Palanisamy D, Kannan E, Bhojraj G. Asian J of Trad Med. 2007;2(2):52-7.

9. Sambat-Kumar R, Sivakumar T, Shanmuga-Sundaram R, Sivakumar P, Nethaji R, et al. Antimicrobial and Antioxidant Activities of Careya arborea Roxb Stem Bark. Iran J Pharmacol Therapeut. 2006;5(1):35-41.

10. Mitra J, Joshi T. Isoflavonoids from the heart wood of Pterocarpus marsupiam. Phytochemistry. 1983;22(10):2326-7.

11. Seshadri TR. Polyphenols of Pterocarpus and Dalbergia woods. Phytochemistry. 1972;11(3):881-8.

12. Kirtikar B. Indian Medicinal Plants. 2nd Ed. Vol I. New Delhi: Materia Medica. 1987; 1:826-7.

13. Mohire NC, Salunkhe VR, Bhise SB, Yadav AV. Cardiotonic activity of aqueous extract of heartwood of Pterocarpus marsupium. 2007;45(6):532-7.

14. Mankani KL, Krishna V, Manjunatha BK, Vidya SM, Singh SJ, Manohara YN, et al. Evaluation of hepatoprotective activity of stem bark of Pterocarpus marsupium Roxb. Indian journal of pharmacology. 2005;37(3):165.

15. Hougee S, Faber J, Sanders A, De Jong RB, Van den Berg WB, Garssen J, et al Selective COX-2 inhibition by a Pterocarpus marsupium extract characterized by pterostilbene, and its activity in healthy human volunteers. Planta medica. 2005;71(5):387-92.

16. Badkhane Y, Yadav AS, Sharma AK, Raghuwanshi DK, Uikey SK, Mir FA, et al Pterocarpus marsupium Roxb-Biological activities and medicinal properties. International Journal of Advances in Pharmaceutical Sciences. 2010;1(4):350-7.

17. Ayurvedic Pharmacopoeia Committee. The Ayurvedic Pharmacopoeia of India, Government of India, Ministry of Health and Family Welfare, Department of Ayurveda, Yoga and Naturopathy, Unani, Siddha and Homoeopathy (AYUSH). 1999.

18. Anon. The wealth of India: Raw Materials. Council of Scientific and Industrial Research, New Delhi, India. 1959.

19. Tiwari MA, Sharma MA, Khare HN. Chemical constituents and medicinal uses of Pterocarpus marsupium Roxb. Flora and Fauna. 2015;21(1):55-9. 
20. Gairola S, Gupta V, Singh B, Maithani M, Bansal P. Phytochemistry and pharmacological activities of Pterocarpus marsupium: A review. Int Res J Pharm. 2010;1:100-4.

21. Kundu M, Schmidt LH. Pterocarpus marsupium Roxb. Seed Leaflet, Mandla Road, Jabalpur India. 2015;482021:163.

22. Srivastava B, Sharma H, Sharma VC, Verma SC, Jadhav AD. Comparative physicochemical, phytochemical and high performance thin layer chromatography evaluation of heart wood and small branches of Pterocarpus marsupium. Research Journal of Pharmacognosy and Phytochemistry. 2016;4(1):53-9.

23. Dharshan S, Veerashekar T, Kuppast IJ, Raghu JD. A review on Pterocarpus marsupium Roxb. International Journal of Universal Pharmacy and Bio Sciences. 2014;3(6):32-41.

24. Jung M, Park M, Lee HC, Kang YH, Kang ES, Kim SK. Antidiabetic agents from medicinal plants. Current medicinal chemistry. 2006;13(10):1203-18.

25. Maurya R, Singh R, Deepak M, Handa SS, Yadav PP, Mishra PK. Constituents of Pterocarpus marsupium: An ayurvedic crude drug. Phytochemistry. 2004; 65(7):915-20.

26. Jain SC, Sharma SK, Kumar R, Rajwanshi VK, Babu BR. A homoisoflavanone from Pterocarpus marsupium. Phytochemistry. 1997;44(4):765-6.

27. Basu K. Indian Medicinal plant. $2^{\text {nd }}$ ed. Delhi: Dehradun Jayed Press. 1975.

28. Katiyar D, Singh V, Ali M. Phytochemical and pharmacological profile of Pterocarpus marsupium: A review. The Pharma Innovation. 2016;5(4):31.

29. Rao AV, Mathew J. 6-hydroxy-3, 5, 7, 4'-tetramethoxyflavone 6-rhamnosidefrom roots of Pterocarpus marsupium. Phytochemistry. 1998;48(7):1259-61.

30. Tripathi J, JoshiT. Phytochemical investigation of roots of Pterocarpus marsupium. Isolation and structural studies of two new flavanone glycosides. Zeitschrift für Naturforschung. 1988;43(3-4):184-6.

31. Mathew J, Rao AV, Rambhav S. Propterol an Antibacterial Agent from Pterocarpusmarsupium. Current Science (Bangalore). 1984;53(11):576-7.

32. Maruthupandian A, Mohan VR. GC-MS analysis of some bioactive constituents of Pterocarpus marsupium Roxb. Int J Chem Tech Res. 2011;3(3):1652-7.

33. Maurya R, Handa SS, Singh R. Inventors: Council of Scientific, Industrial Research (CSIR), and assignee. Glucopyranoside and process of isolation thereof from pterocarpus marsupium pharmaceutical composition containing the same and use thereof. United States patent US. 2003;6:617-313.

34. Rajinder S, Rakesh M, Satti NK. Pterocarposide, an isoaurone C-glucoside of Pterocarpus marsupium. Pterocarposide Tetrahedron Letters 41. Phyto-chemistry. 2000:41(10):1579-81

35. Rajesh KG, Rakesh M, Raja R. Dynamic NMR investigation of two new interconvertible diasteriomeric epimers of natural 2-benzyl-2-hydroxybenzofuranone derivative from Pterocarpus marupium. Phytochemistry. 1996;44:765-6.

36. Londonkar RL, Hugar AL. GC-MS profiling of bioactive components from aqueous extract of Pterocarpus marsupium I J of Chem Tech Research. 2017:2455-9555.

37. Jahromi MF, Ray AB, Chansouria JP. Antihyperlipidemic effect of flavonoids from Pterocarpus marsupium. Journal of Natural Products. 1993;56(7):989-94.

38. Grover JK, Vats V, Yadav SS. Pterocarpus marsupium extract (Vijayasar) prevented the alteration in metabolic patterns induced in the normal rat by feeding an adequate diet containing fructose as sole carbohydrate. Diabetes, Obesity and Metabolism. 2005;7(4):414-20.

39. Patil R, Patil R, Ahirwar B, Ahirwar D. Current status of Indian medicinal plants with antidiabetic potential: A review. Asian Pacific Journal of Tropical Biomedicine. 2011;1(2):291-8

40. Chandel HS, Pathak AK, Tailang M. Standardization of some herbal antidiabetic drugs in polyherbal formulation. Pharmacognosy research. 2011;3(1):49.

41. The Ayurvedic Pharmacopoeia of India, Part I. Govt. of India. 1st ed. Department of Indian System of Medicine and Homoeopathy. 1999;2:191.

42. Harinarayan SC, Pathak AK, Mukul T. Standardisation of Some Herbal Antidiabetic drugs in Polyherbal Formulations. Pharmacognosy Res. 2011;3(1):49-56.

43. Kanetkar P, Singhal R, Kamat M. Gymnema sylvestre: A Memori. 2016. https:// www.ncbi.n/m.nih.gov/pmc/article-October 12.

44. Dhanabal SP, Kokate CK, Ramanathan M, Kumar EP, Suresh B. Hypoglycaemic activity of Pterocarpus marsupium Roxb. Phytotherapy research. 2006;20(1):4-8.

45. Pant DR, Pant ND, Saru DB, Yadav UN, Khanal DP. Phytochemical screening and study of antioxidant, antimicrobial, antidiabetic, anti-inflammatory and analgesic activities of extracts from stem wood of Pterocarpus marsupium Roxburgh. Journal of intercultural ethnopharmacology. 2017;6(2):170.

46. Narendar K, Nayak MN, Jamadar MG, Patil AM, Anand S. Comparison of the effect of Pterocarpus marsupium with Pioglitazone in dexamethasone-induced insulin resistance. Asian J Pharm Clin Res. 2016;9(2):211-4.

47. Manickam M, Ramanathan M, Farboodniay Jahromi MA, Chansouria JP, Ray AB. Antihyperglycemic activity of phenolics from Pterocarpus marsupium. Journal of natural products. 1997;60(6):609-10.

48. Anandharajan R, Pathmanathan K, Shankernarayanan NP, Vishwakarma RA, Balakrishnan A. Upregulation of GLUT-4 and PPAR $\gamma$ by an isoflavone from Pterocarpus marsupium on L6 myotubes: A possible mechanism of action. Journal of ethnopharmacology. 2005;97(2):253-60.

49. Garud N, Garud A, Balakrishnan N, Tomar V. Antidiabetic activity of ethanolic extract of Trigonella foenium seeds Pterocarpus marsupium wood. An interna- tional Biannual journal. 2009;17:45.

50. Chakravarthy BK, Saroj G, Gambhir SS, Gode KD. Pancreatic beta cell regeneration-a novel antidiabetic mechanism of Pterocarpus marsupium roxb. Indian journal of Pharmacology. 1980;12(2):123

51. Kirana H, Girish HN, Srinivasan BP. The Study of aqueous extract of Pterocarpus marsupium Roxb. On cytokine TNF- $\alpha$ in type 2 diabetic rats. IJP. 2010;42(6):392-6.

52. Mohankumar SK, O'Shea T, McFarlane JR. Insulinotrophic and insulin-like effects of a high molecular weight aqueous extract of Pterocarpus marsupium Roxb. Hardwood. Journal of ethnopharmacology. 2012;141(1):72-9.

53. Chakravarthy BK, Gode KD. Isolation of (-)-epicatechin from Pterocarpus marsupium and its pharmacological actions. Planta medica. 1985;51(1):56-9.

54. Singh PK, Baxi D, Banerjee S, Ramachandran AV. Therapy with methanolic extract of Pterocarpus marsupium Roxb and Ocimum sanctum Linn reverses dyslipidemia and oxidative stress in alloxan induced type I diabetic rat model. Experimental and Toxicologic Pathology. 2012;64(5):441-8.

55. Shah DS. A preliminary study of the hypoglycemic action of heartwood of Pterocarpus marsupium roxb. Indian Journal of Medical Research. 1967;55(2):166-8.

56. Abirami B, Gayathri P, Uma D. In vitro antioxidant potential of Pterocarpus marsupium bark. Int J Chem Pharm Sci. 2012;3:17-24

57. Kumaravel RS, Maleeka Begum SF, Parvathib H, Senthil Kumar CM. Phytochemical screening and in vitro antioxidant activity of ethyl acetate leaf extracts of Pterocarpus marsupium Roxb (Fabaceae). Int J Curr Sci. 2013:9:46-55.

58. Rajalakshmi G, Radhika T, Prasad N. Antioxidant activity of red Kino tree using frog heart model. Pharmacology online. 2008;3:26-31.

59. Gupta $P$, Jain V, Pareek A, Kumari $P$, Singh $R$, Agarwal $P$, et al. Evaluation of effect of alcoholic extract of heartwood of Pterocarpus marsupium on in vitro antioxidant, anti-glycation, sorbitol accumulation and inhibition of aldose reductase activity. Journal of traditional and complementary medicine. 2017;7(3):307-14

60. Devipriya D, Gowri S, Nideesh TR. Hepatoprotective effect of Pterocarpus marsupium against carbon tetrachloride induced damage in albino rats. Ancient science of life. 2007;27(1):19.

61. Dilpesh J, Patel I, Soma R. Anti-diarrhoeal activity of ethanolic heartwood extract of Pterocarpus marsupium. 2011;1:552-9

62. Remsberg CM, Yáñez JA, Ohgami Y, Vega-Villa KR, Rimando AM, Davies NM. Pharmacometrics of pterostilbene: Preclinical pharmacokinetics and metabolism, anticancer, antiinflammatory, antioxidant and analgesic activity. Phytotherapy Research. 2008;22(2):169-79.

63. Pan $\mathrm{MH}$, Chang $\mathrm{YH}$, Badmaev $\mathrm{V}$, Nagabhushanam $\mathrm{K}$, Ho CT. Pterostilbene induces apoptosis and cell cycle arrest in human gastric carcinoma cells. J of Agricultural and Food Chemistry. 2007;55(19):7777-85.

64. Londonkar RL, Hugar AL. Physicochemical, phytochemical profiling and antimicrobial activity of Pterocarpus marsupium. International Journal of Pharmaceutical Sciences and Research. 2017;8(5):2177.

65. Deepa R, Manjunatha H, Krishna V, Kumara Swamy BE. J Biotechnol Biomater 2014;4(1):166-70

66. Kachhawa JB, Sharma N, Tyagi S, Gupta RS, Sharma KK. Int J of Phar and Pharmac Sci. 2012 4(1):67-8.

67. Ahmad H, Rajagopal K. Pharmacology of Pterocarpus marsupium Roxb. Medicinal Plant Research. 2015;5(3):1-6.

68. Rajeeb M, Usman M, Pathan EK, Jain BV, Pawar SR. J of Ph and Sci Innov. 2012:1-5.

69. Halagappa K, Girish HN, Srinivasan BP. Indian J Pharmacol. 2010;42(6):392-6.

70. Tchamadeu MC, Dzeufiet PD, Nana P, Kouambou CC, Tsofack FN, Allard $\mathrm{J}$, et al. Acute and sub-chronic oral toxicity studies of an aqueous stem bark extract of Pterocarpus (Papilionaceae) in rodents. J Ethnopharmacol. 2011;133(2):329-35.

71. Mahnaz M, Swapnil S, Devasagayam G, Saroj S. J of Comp and Int Med. 2010;7(1):14.

72. Bhupendra $\mathrm{C}$, Amrendra KC. Memory enhancing activity of methanolic extract of Pterocarpus marsupium Roxb. Phytopharmacol. 2012;2(1):72-80.

73. Goel RK, Bhattacharya SK. Gastroduodenal mucosal defence and mucosal protective agents. Indian Journal of Experimental Biology. 1991;29(8):701.

74. Takehara KO, Tashima KI, Takeuchi KO. Alterations in duodenal bicarbonate secretion and mucosal susceptibility to acid in diabetic rats. Gastroenterology. $1997 ; 112(2): 418-28$

75. Sikdar A, Biswas A, Bhattacharya S, Biswas M. Assessment of analgesic activity of Pterocarpus marsupium leaf extracts in Swiss albino mice. Journal of Advanced Pharmacy Education and Research. 2013;3(1):42-5.

76. Tippani R, Porika M, Allenki V, Narsimha RY, Christopher T. Antioxidant and Analgesic Activities of Pterocarpus marsupium Roxb. Journal of Herbs, Spices and Medicinal Plants. 2010;16(1):63-8.

77. Vats V, Yadav SP, Biswas NR, Grover JK. Anti-cataract activity of Pterocarpus marsupium bark and Trigonella foenum-graecum seeds extract in alloxan diabetic rats. Journal of ethnopharmacology. 2004:93(2-3):289-94.

78. Vats V, Grover JK, Rathi SS. J of Ethnopharmacol. 2002;79(1):95-100.

79. Mohammadi M, Gaikwad SS, Devasagayam T, Ghaskadbi SS. Genotoxic 
Assessment of Pterocarpus marsupium Extract. Journal of Complementary and Integrative Medicine. 2010;7(1):1-11.

80. Chauhan NS, Sharma V, Dixit VK, Thakur M. Bio Med Res Int. 2014:1-20.

81. Dhir GG, Mohan G, Verma RB, Mishra SS. Studies on the Antifungal Activity of Pterocarpus marsupium: A Clinical Evaluation. Indian journal of dermatology, venereology and leprology. 1982;48(3):154-6.

82. Panda SK, Padhy RP, Ray GD, Hial DC. Phytochemical investigation and anthelmintic activity of various leaf extracts of Pterocarpus marsupium roxb. 2015;639-45.

\section{GRAPHICAL ABSTRACT}

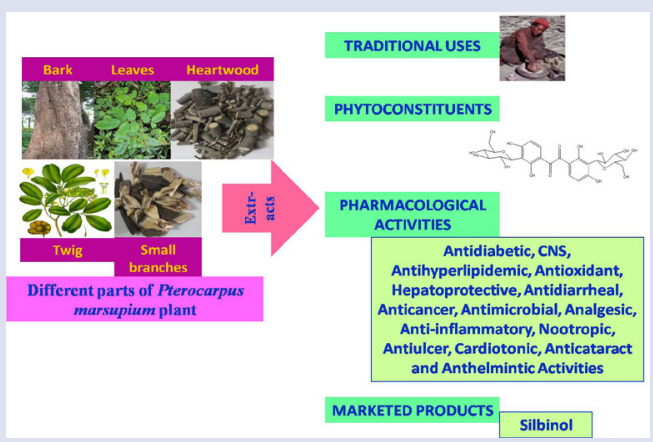

\section{SUMMARY}

- The current review aimed to define the phytochemical and pharmacological aspects of $P$. marsupium which will have been help in the researchers for further qualitative research.

- Researchers have been stated the presence of several phytoconstituents in $P$. marsupium and also their pharmacological activities.

- P. marsupium is a decent source of tannins and flavonoids hence, used as influential astringent, anodyne, cooling, regenerating agent and also used for the treatments of leprosy, leucoderma, toothache, fractures, diarrhea, passive hemorrhage, and dysentery, bruises and diabetes.

- It is also used to treat rheumatoid arthritis, gout, diabetic anemia, indigestion, asthma, cough, discoloration of hair, bronchitis, ophthalmic complications, elephantiasis and erysipelas.

\section{ABOUT AUTHORS}

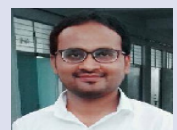

Mohd Saidur Rahman: Research scholar, Department of Pharmacy, Integral University, Lucknow, Uttar Pradesh -226026, INDIA

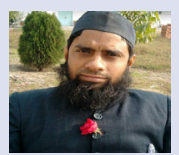

Dr. Md. Mujahid: Associate Professor, Department of Pharmacy, Integral University, Lucknow, Uttar Pradesh -226026, INDIA

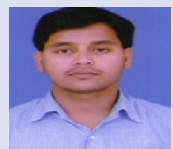

Mohd Aftab Siddiqui: Assistant Professor, Department of Pharmacy, Integral University, Lucknow, Uttar Pradesh -226026, INDIA

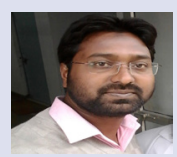

Dr. Md. Azizur Rahman: Assistant Professor, Department of Pharmacy, Integral University, Lucknow, Uttar Pradesh -226026, INDIA

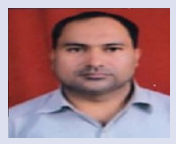

Dr. Muhammad Arif: Associate Professor, Department of Pharmacy, Integral University, Lucknow, Uttar Pradesh -226026, INDIA

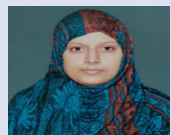

Shimaila Eram: Research Scholar, Department of Pharmacy, Integral University, Lucknow, Uttar Pradesh -226026 , INDIA

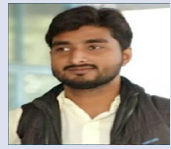

Anayatullah Khan: Research Scholar, Department of Pharmacy, Integral University, Lucknow, Uttar Pradesh -226026, INDIA

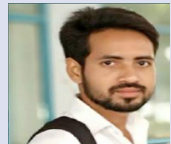

Md Azeemuddin: Research Scholar, Department of Pharmacy, Integral University, Lucknow, Uttar Pradesh -226026, INDIA

Cite this article: Rahman MS, Mujahid Md, Siddiqui MA, Rahman MS, Arif M, Eram S, Khan A, Azeemuddin Md. Ethnobotanical uses, Phytochemistry and Pharmacological Activities of Pterocarpus marsupium: A Review. Pharmacog J. 2018;10(6)Suppl:s1-s8. 